\title{
The central-marginal hypothesis in acridid Orthoptera: A critique of Colombo's (2012) article
}

\author{
Claudio J. BIDAU ${ }^{1}$ and Dardo A. MARTí ${ }^{2,3}$ \\ ${ }^{1}$ Paraná y Los Claveles, 3300 Posadas, Misiones, Argentina; e-mail: bidau47@yahoo.com \\ ${ }^{2}$ Laboratorio de Genética Evolutiva, Facultad de Ciencias Exactas, Químicas y Naturales, Universidad Nacional de Misiones, Félix \\ de Azara 1552, 3300 Posadas, Misiones, Argentina; e-mail: darmarti@yahoo.com.ar \\ ${ }^{3}$ IBS-CONICET
}

Key words. Orthoptera, Acrididae, Dichroplus pratensis, abiotic factors, environmental gradients, marginal populations, peripheral populations, polymorphism, species limits, species range

\begin{abstract}
We discuss and criticise the contention of Colombo (2012) that the central-marginal model does not apply to three species of chromosomally polymorphic acridid grasshoppers, and that chromosomal clines in these species are a consequence of temperature gradients. We also discuss Colombo's interpretation of our own results on the South American melanopline grasshopper, Dichroplus pratensis Bruner.
\end{abstract}

In a recent paper, Colombo (2012) discussed the application of the central-marginal hypothesis using as model organisms three species of South American grasshoppers that exhibit chromosomal polymorphisms (Robertsonian translocations and pericentric inversions) which he also compared to our own data on the Neotropical species Dichroplus pratensis Bruner (Acrididae: Melanoplinae). This species shows a clear central-marginal pattern, not only with regard to chromosomal polymorphisms (Robertsonian translocations and B chromosomes) but also many other life-history characteristics (Bidau \& Martí, 2002; Bidau et al., 2012).

The limits of the geographic range of a species are of utmost relevance for the understanding of its evolutionary dynamics. The Ludwig effect (Ludwig, 1950; Mayr, 1963; Soulé, 1973), centrifugal speciation (Brown, 1957), the "abundant centre" distribution (Sagarin \& Gaines, 2002; Sagarin et al., 2006; Tuya et al., 2008), and the central-marginal "model" (Prakash, 1973; Brussard, 1984; Yamashita \& Polis, 1995, Garner et al., 2004; Guo et al., 2005; Bidau \& Martí, 2008; Munwes et al., 2010; Bidau et al., 2012) have attempted to resolve this issue (see the relevant papers for descriptions and definitions therein). In fact, the basic ideas of Mayr $(1954,1982)$ of speciation via the founder principle and genetic revolutions were based on the properties of peripheral populations (Templeton, 1980; Carson \& Templeton, 1984).

In order to determine whether or not a polymorphic species obeys the central-marginal model, it is necessary to study its whole geographic range, especially when this is very large. Furthermore, if the pattern is found to exist, gradients of polymorphism will be found from the center of the distribution (ecologically optimal) to its margins; thus, studying only one extreme of the geographic distribution will undoubtedly reveal gradients of different type in relation to abiotic and biotic factors but will not show other types of large-scale patterns. In addition, environmental conditions such as temperature, precipitation, evapo-transpiration, water balance, etc. will change from the center to the borders of the distribution, as will other factors such as primary productivity, resource availability, or intensity of predation. Many gradients such as environmental factors, life history characteristics of species, and also chromosomal polymorphisms, may be superimposed in different ways in different parts of the range. Lastly, speciation is usually facilitated in species with a large distribution mainly as a result of geographical isolation (allopatric isolation), the intrinsic heterogeneity of the environment, and by evolutionary pressures towards specialisation and range limits (Turelli et al., 2001).

But the question may well be asked: what is a marginal population? According to Soulé (1973) defining a marginal population is problematic. Two kinds of definition are possible, one static, one dynamic. The first states "... a marginal population is one in which the individuals are relatively sparsely distributed and show effects of physiological stress, e.g. starvation, dehydration, or stunting." (Soulé, 1973). Conversely, the dynamic definition states that "a marginal population undergoes great fluctuations in numbers and has a high probability of extinction" (Soulé, 1973).

Properties of species populations at the margins of their distribution are multiple and do not only pertain to chromosomal polymorphisms (indeed, many species are not chromosomally polymorphic) but may involve natural history (i.e. ecology) and demographic characteristics as well as genetic diversity, body size and size variability, sexual dimorphism, and many others factors (Sperlich et al., 1977; Brakefield, 1985; Kluth \& Bruelheide, 2005; Mandák et al., 2005; Angert, 2006; Antonovics et al., 2006; Eckert et al., 2008; Kawecki, 2008; Antonovics, 2009). Furthermore, the extent of geographic range 
probably influences the magnitude of chromosomal evolution (Robbins et al., 1983).

The classic view (Lawton, 1993) predicts that marginal populations are more prone to extinction and genetically less diverse than central ones, because they usually occur in less favourable habitats and at lower and more variable densities. However, marginal populations are frequently relatively better-adapted to unfavourable conditions (but perform poorly under most other conditions) and are essential reservoirs of genetic diversity (Hoffmann \& Blows, 1994). Further knowledge about such populations could prove highly beneficial for the conservation of particular endangered species in the light of predicted climate change (Hampe \& Petit, 2005). In addition, the central-marginal pattern is part of a more general biological problem - that of the limits of species ranges (Antonovics, 1976; Parsons, 1991; Brown et al., 1996; Gaston, 1996; Sexton et al., 2009; Hardie \& Hutchings 2010; Hargrove, 2010). As Mayr (1963) stated long ago, "The species border is one of the most interesting phenomena of evolution and ecology, yet as a scientific problem it has been almost totally ignored". It is also important to note that the central-marginal model is not a law but a pattern (such as Bergmann's or other ecogeographic rules). In the sense of Lawton (1999), "Patterns are regularities in what we observe in nature; that is, they are 'widely observable tendencies'". Since they are not laws, it follows that exceptions are naturally expected. In order to determine the exceptions we must thoroughly explore the pattern, or its absence.

All the grasshopper species (Orthoptera: Acrididae) used by Colombo (2012) as examples for challenging the reality of the central-marginal pattern have vast geographic distributions (Eades et al., 2012). For example, the geographic distribution of Cornops aquaticum (Bruner) is millions of square $\mathrm{km}$, from the borders of USA and Mexico, throughout Central America and most of South America reaching almost the north of the Argentine Patagonia (Adis et al., 2007). Leptysma argentina Bruner is distributed in Argentina, Paraguay, Uruguay, and eastern Brazil (Roberts, 1977). Trimerotropis pallidipennis (Burmeister) occurs in western North America, in Ecuador, and Argentina but its distribution is probably much larger. However, recent molecular data (Husemann et al., 2013) suggest that the Argentine form could even be a distinct species.

In none of these three species was the entire distribution range examined but rather, only geographically peripheral areas. The case of Dichroplus pratensis (Melanoplinae, Acrididae) is however different: insects from almost the entire geographic range have been analysed with respect to chromosomal polymorphisms and their relation to environmental factors, body size, and morphological variability. The studied region spanned 21 degrees of latitude (from lat $23.92^{\circ} \mathrm{S}$ to lat $45.95^{\circ} \mathrm{S}$ ), and 0 to 2,474 m above sea level (Bidau \& Martí, 2002, 2005, 2007; Bidau et al., 2012) with an altitudinal range of $0-2,500 \mathrm{~m}$ above sea level. The habitats involved represented a wide variety of habitats, such as the Puna high- lands of Jujuy province in the north, the Patagonian monte and steppe to the south, the low Andes up to 1,500 $\mathrm{m}$ asl (all peripheral and ecologically marginal localities), the dry and humid Pampas and transitional regions such as Sierra de la Ventana (central and ecologically optimal), and the north-central Atlantic coast (peripheral but ecologically optimal).

From our own studies, it is clear that D. pratensis shows a typical central-marginal geographic pattern, where frequency of chromosomal fusions decreases gradually to zero in marginal areas (i.e. Patagonia and the Puna highlands). These chromosomal clines obviously coincide with a number of environmental clines, since climatic factors vary gradually towards the margins of the distribution range involving latitude, longitude, and elevation. All these factors were not taken into account by Colombo (2012) in his revision of the literature pertaining to $D$. pratensis, such that his review undoubtedly missed very important and pertinent publications. Additionally, Colombo's (2012) stress on temperature does not seem warranted according to the available published information: many abiotic factors correlated with marginality may affect characteristics of populations. For instance, seasonality is by far the most important factor that controls life histories of insects in marginal environments (Danks, 2006, 2007). But Colombo (2012) does not produce any hypothesis relating temperature with acridid grasshopper chromosomal polymorphism. We did study temperature as well as many other abiotic factors in relation to chromosomal variability and morphological characteristics of D. pratensis (see Bidau et al., 2012 for review), but correlations were found not to be necessarily causal. Temperature gradients will always be found when analyzing biological aspects of large geographic species population distributions and their co-linearity with chromosomal gradients in the present case does not mean that temperature is necessarily responsible for the chromosomal cline observed. Temperature may be influencing some other abiotic or biotic factor that determines the chromosome cline more directly, or may not have any influence at all: both clines may simply be coincidental. Thus, one of the conclusions reached by the author is not justified (p. 322): "When temperature is taken into account (judging from the published fusion frequencies and latitude and altitude, Bidau \& Martí, 2002), a clear correlation emerges between minimum temperature and average number of fusions per population. Admittedly, the authors have a point since, from the scatter plot, it is easily seen that the populations from the central temperatures still stray apart from the line and into higher fusion frequencies. I am not claiming that the authors are wrong in proposing a central-marginal pattern in this case. Even so, caution is here necessary and all variables should be considered. Clearly, correlation with environmental variables has not previously been taken into account."

Of course the various chromosomal clines of $D$. pratensis are correlated with temperature towards the margins of the range because of the inherent characteristics of this distribution. But many other life-history characteristics of 
the species are co-linear with temperature: body size, body size variability, sexual size dimorphism, length of growing season, time available for reproduction, to mention but a few, which does not mean that temperature per se is the main factor directly behind all these significant clines (Bidau et al., 2012). As a counter example, it is worth considering body size. The species $D$. pratensis follows the converse of Bergmann's rule (Bidau \& Martí, 2007, 2008); thus, individuals become increasingly smaller towards cooler regions. However, temperature is probably not the determinant of this phenomenon, but rather increasing seasonality that produces more unpredictable environments, shortening of the growing season, and decreased resource availability (Bidau et al., 2012). Furthermore, relating temperature to chromosomal polymorphism without a supporting hypothesis or mechanism, essentially represents a uni-dimensional and rather simplistic explanation of a possibly much more complex phenomenon.

A further, but by no means less important possibility in the formation of chromosomal clines within the distribution of a species, is that such clines could be the result of historical factors more than of the agency of natural selection. It is considered that chromosomal mutations are unique events, not recurrent (White, 1973). Hence, if a new chromosomal rearrangement appeared in an ecologically central population, it is to be expected that the mutation would be more frequent near the place where it originated, and less common in more remote areas where its arrival through migration is less likely. It is also possible that from center to margin, the migration route parallels existing environmental clines, thereby giving the impression that temperature is - for example - driving the chromosome cline.

What is most puzzling about Colombo's (2012) discussion is implicit in the following excerpts from his work: "In the case of $L$. argentina, all of these indications were found $[. .$. . only that the "smoking gun" of temperature as a cause for karyotype frequency distribution has not yet been detected (emphasis added). A stronger hint is given in the case of $T$. pallidipennis, since the cline is not only latitudinal but also altitudinal [....]" (Discussion, p. 321). These are correlations, hints, not hypotheses relating to the actual practical process/es involved. Also, "With no definite link between clines and environment, (emphasis added) it must be reckoned that other factors may be responsible for the clinal variation." (Discussion, p. 321). Thus, he proposes somewhat confusingly, certain ideas derived from the cytogenetic properties of the rearranged chromosomes independent of temperature in relation to the segregation of trivalents of the Robertsonian species, and the absence of negative heterosis. It is now widely accepted that negative heterosis is not a precondition for chromosomal evolution, but probably the effects of rearrangements on recombination suppression are (Rieseberg, 2001; Brown \& O’Neill, 2010).

Moreover, of the species used by Colombo (2012) as examples of his general thesis, one cannot be sure what kind of populations the author actually analysed. In the cases of C. aquaticum and L. argentina, they are undoubtedly geographically peripheral in terms of distribution. The author uses a biased criterion when referring to marginal populations: a geographic, not ecological one. Some authors have used the terms "marginal" or "peripheral" as equivalents but this use lacks rigor. According to Soulé (1973): "First, not all marginal populations are peripherally located. Topographic relief can impose marginal conditions in the geographic center of a range by producing deserts, rain shadows, and various altitudinal effects. Second, not all peripheral populations are ecologically marginal".

Two other affirmations of Colombo deserve comment: "These aforementioned examples emphasise the dangers of over-generalization when discussing chromosomal polymorphisms, and suggests that such polymorphisms should be considered very much in a case-specific manner in terms of the particular genetic system under study." (Abstract, p. 317). Also, "This suggests that the central-marginal model is not automatically applicable to all chromosome polymorphisms, but that in some cases environmental clines are the reason of the geographic distribution of chromosome polymorphisms in natural populations." (Discussion, p. 322).

Previous to Colombo's paper, studies on the chromosome variability of $D$. pratensis only dealt with a centralmarginal pattern of distribution in this chromosomally polymorphic grasshopper species (Bidau \& Martí, 2002, 2005; Miño et al., 2011; Bidau et al., 2012). As the author correctly says, this is clear-cut case of the discussed pattern. However, we never generalised or 'automatically' applied our conclusions to other cases of chromosomal polymorphism within the grasshopper group, especially because no other case had been studied at the appropriate geographic level at that time! Conversely, Colombo applies his ad hoc idea of temperature-driven chromosomal gradients to all four grasshopper species involved, and without supporting evidence besides circumstantial correlations.

Finally, as stated above, we are discussing a pattern of grasshopper variability that can assume many forms depending on the nature of the character studied. Many variants of the central-marginal pattern have been described (Eckert et al., 2008 and references therein) without invaliding the trend per se. For chromosomal polymorphisms, only the four cases here mentioned have been reported: one, $D$. pratensis leaves little doubt as to its prevailing chromosomal patterning; the others need substantiation via a thorough investigation of the whole geographic distribution of the species concerned. Certainly four species examples are not enough to confirm the general validity of a particular ascribed mechanism in relation to observed ecogeographic patterns of the chromosomes of the acridid grasshopper populations examined, and only additional empirical data can hope to verify such assertions.

ACKNOWLEDGMENTS. The authors thank V.X. Rodríguez (Posadas, Argentina), C.I. Miño (São Carlos, Brazil), and R. Melano (Toronto, Canada) for critical reading of the manuscript. 
DAM acknowledges the continuous support of Consejo Nacional de Investigaciones Científicas y Técnicas (CONICET). We are also extremely grateful to J.P. Camacho and an anonymous reviewer for suggestions that substantially improved the manuscript, and H.D. Loxdale for improving the English.

\section{REFERENCES}

Adis J., Bustorf E., Lhano M.G., Amedegnato C. \& Nunes A.L. 2007: Distribution of Cornops grasshoppers (Leptysminae: Acrididae: Orthoptera) in Latin America and the Caribbean Islands. - Stud. Neotrop. Fauna Environ. 42: 11-24.

Angert A.L. 2006: Demography of central and marginal populations of monkeyflowers (Mimulus cardinalis and $M$. lewisii). - Ecology 87: 2014-2025.

Antonovics J. 1976: The nature of limits to natural selection. Ann. Missouri Bot. Gard. 63: 224-247.

Antonovics J. 2009: The effect of sterilizing diseases on host abundance and distribution along environmental gradients. Proc. R. Soc. (B) 276: 1443-1448.

Antonovics J., McKane A.J. \& Newman T.J. 2006: Spatiotemporal dynamics in marginal populations. - Am. Nat. 167: $16-27$.

Bidau C. \& Martí D.A. 2002: Geographic distribution of Robertsonian fusions in Dichroplus pratensis (Melanoplinae, Acrididae): the central-marginal hypothesis reanalysed. Cytogenet. Genome Res. 96: 66-74.

BidAu C.J. \& MARTí D.A. 2005: Variability along a latitudinal gradient in the chiasma frequency and morphological characters of Dichroplus pratensis (Orthoptera: Acrididae). - Eur. J. Entomol. 102: 1-12.

BIDAU C.J. \& MARTí D.A. 2007: Clinal variation of body size in Dichroplus pratensis (Orthoptera: Acrididae): inversion of Bergmann's and Rensch's rules. - Ann. Entomol. Soc. Am. 100: $850-860$.

BidAu C.J. \& MARTí D.A. 2008: Geographic and climatic factors related to a body-size cline in Dichroplus pratensis Bruner, 1900 (Acrididae, Melanoplinae). - J. Orthopt. Res. 17: 149-156.

Bidau C.J., Miño C.I., Castillo E.R. \& Martí D.A. 2012: Effects of abiotic factors on the geographic distribution of body size variation and chromosomal polymorphisms in two neotropical grasshopper species (Dichroplus: Melanoplinae: Acrididae). - Psyche (in press) doi:10.1155/2012/863947

BRAKEFIELD P. 1985: Studies of colour polymorphism in some marginal populations of the aposematic jersey tiger moth $\mathrm{Cal}$ limorpha quadripunctaria. - Biol. J. Linn. Soc. 26: 225-241.

Brown J.D. \& O’Neill R.J. 2010: Chromosomes, conflict, and epigenetics: chromosomal speciation revisited. - Annu. Rev. Genomics Hum. Genet. 11: 291-316.

Brown J.H., Stevens G.C. \& Kaufman D.M. 1996: The geographic range: size, shape, boundaries, and internal structure. - Annu. Rev. Ecol. Syst. 27: 597-623.

Brown W.L. JR. 1957: Centrifugal speciation. - Quart. Rev. Biol. 32: 247-277.

BRUSSARD P.F. 1984: Geographic patterns and environmental gradients: the central-marginal model in Drosophila revisited. - Annu. Rev. Ecol. Syst. 15: 25-64.

Carson H.L. \& Templeton A.R. 1984: Genetic revolutions in relation to speciation phenomena: the founding of new populations. - Annu. Rev. Ecol. Syst. 15: 97-131.

Colombo P.C. 2012: Against the central-marginal model: Three cases in chromosomally polymorphic grasshoppers (Orthoptera: Acrididae). - Eur. J. Entomol. 109: 317-324.
DANKS H.V. 2006: Key themes in the study of seasonal adaptations in insects II. Life-cycle patterns. - Appl. Entomol. Zool. 41: 1-13.

DANKS H.V. 2007: The elements of seasonal adaptations in insects. - Can. Entomol. 139: 1-44.

Eades D.C., Otte D., Cigliano M.M. \& Braun H. 2012: Orthoptera Species File Online. Version 2.0/4.1. [August 9, 2012] <http://Orthoptera.SpeciesFile.org $>$.

Eckert C.G., SAmis K.E. \& Lougheed C. 2008: Genetic variation across species' geographical ranges: the central-marginal hypothesis and beyond. - Mol. Ecol. 17: 1170-1188.

Garner T.W.J., Pearman P.B. \& Angelone S. 2004: Genetic diversity across a vertebrate species' range: a test of the central-peripheral hypothesis. - Mol. Ecol. 13: 1047-1053.

GASTON K.J. 1996: Species-range-size distributions: patterns, mechanisms and implications. - Trends Ecol. Evol. 15: 197-201.

Guo Q., Taper M., Shoeneberger M.M. \& Brindle J.R. 2005: Spatial-temporal population dynamics across species range: from centre to margin. - Oikos 108: 47-57.

Hampe A. \& Petit R.J. 2005: Conserving biodiversity under climate change: the rear edge matters. - Ecol. Lett. 8: 461-467.

Hardie D.C. \& Hutchings J.A. 2010: Evolutionary ecology at the extremes of species' ranges. - Environ. Rev. 18: 1-20.

Hargrove L.J. 2010: Limits to Species' Distributions: Spatial Structure and Dynamics of Breeding Bird Populations Along an Ecological Gradient. Ph.D. thesis, University of California, Riversdale, $122 \mathrm{pp}$.

Hoffmann A.A. \& Blows M.W. 1994: Species borders: ecological and evolutionary perspectives. - Trends Ecol. Evol. 9: $223-227$.

Husemann M., Guzman N.V., Danley P.D., Cigliano M.M. \& CONFAlonieri V.A. 2013: Biogeography of Trimerotropis pallidipennis (Acrididae: Oedipodinae): deep divergence across the Americas. - J. Biogeogr. 40: 261-273.

KaweCKI T.Z. 2008: Adaptation to marginal habitats. - Annu. Rev. Ecol. Syst. Evol. 39: 321-342.

Kluth C. \& Bruelheide H. 2005: Central and peripheral Hornungia petraea populations: patterns and dynamics. $-J$. Ecol. 93: 584-595.

LAWTON J.H. 1993: Range, population abundance and conservation. - Trends Ecol. Evol. 8: 409-413.

LawTON J.H. 1999: Are there general laws in ecology? — Oikos 84: 177-192.

LuDwig W. 1950: Zur Theorie der Konkurrenz. Die Annidation (Einnischung) als funfter Evolutions faktor. - Neve Ergeb. Probleme Zool. Klatt-Festschrift 1950: 516-537.

Mandák B., Bímová K., PlačKová I., Mahelka V. \& Chrtek J. 2005: Loss of genetic variation in geographically marginal populations of Atriplex tatarica (Chenopodiaceae). - Ann. Bot. 96: 901-912.

MAYR E. 1954: Change of genetic environment and evolution. In Huxley J.E., Hardy A.C. \& Ford E.B. (eds): Evolution as a Process. Allen and Unwin, London, pp. 157-180.

Mayr E. 1963: Animal Species and Evolution. Belknap Press, Harvard, $797 \mathrm{pp}$.

MAYR E. 1982: Processes of speciation in animals. In Barigozzi C. (ed.): Mechanisms of Speciation. Liss, New York, pp. 411-433.

Miño C.I., Gardenal C.N. \& Bidau C.J. 2011: Small scale variation within a mosaic hybrid zone of Dichroplus pratensis (Acrididae). - J. Hered. 102: 184-195.

Munwes I., Geffen E., Roll U., Friedmann A., Daya A., TikoCHINSKI Y. \& GAFNY S. 2010: The change in genetic diversity down the core-edge gradient in the eastern spadefoot toad (Pelobates syriacus). — Mol. Ecol. 19: 2675-2689. 
PARSONS P.A. 1991: Evolutionary rates: stress and species boundaries. - Annu. Rev. Ecol. Syst. 22: 1-18.

Prakash S. 1973: Patterns of gene variation in central and marginal populations of Drosophila robusta. - Genetics $\mathbf{7 5}$ : 347-369.

RIESEBERG L.H. 2001: Chromosomal rearrangements and speciation. - Trends Ecol. Evol. 17: 351-358.

Robbins L.W., Moulton M.P. \& BAKer R.J. 1983: Extent of geographic range and magnitude of chromosomal evolution. - J. Biogeogr. 10: 533-541.

RoBerTs H.R. 1977: A revision of the tribe Leptysmini except the genus Cylindrotettix (Orthoptera: Acrididae: Leptysminae). - Proc. Acad. Nat. Sci. Philadelphia 129: 33-69.

SAGARIN R.D. \& GaInES S.D. 2002: The "abundant centre" distribution: to what extent is it a biogeographical rule? - Ecol Lett. 5: $137-147$.

SAGarin R.D., Gaines S.D. \& GaYlord B. 2006: Moving beyond assumptions to understand abundance distributions across the ranges of species. - Trends Ecol. Evol. 21: $524-530$.
Sexton J.P., McIntyre P.J., Angert A.L. \& Rice K.J. 2009: Evolution and ecology of species range limits. - Annu. Rev. Ecol. Syst. Evol. 40: 415-436.

SoulÉ M. 1973: The epistasis cycle: a theory of marginal populations. - Annu. Rev. Ecol Syst. 4: 165-187.

Sperlich D., Feuerbach-Mravlag H., Lange P., Michaelidis A. \& Pentzos-Daponte A. 1977: Genetic load and viability distribution in central and marginal populations of Drosophila subobscura. - Genetics 86: 835-848.

TEMPLETON A.R. 1980: The theory of speciation via the founder principle. - Genetics 94: 1011-1038.

Turelli M., Barton N.H. \& Coyne J.A. 2001: Theory and speciation. - Trends Ecol. Evol. 16: 330-343.

Tuya F., Wernierg T. \& Thomsen M.S. 2008: Testing the 'abundant centre' hypothesis on endemic reef fishes in southwestern Australia. - Mar. Ecol. Prog. Ser. 372: 225-230.

White M.J.D 1973: Animal Cytology and Evolution. 3rd ed. Cambridge University Press, Cambridge, UK, 961 pp.

Yamashita T. \& Polis G.A. 1995: A test of the central-marginal model using sand scorpion populations (Paruroctonus mesaensis, Vaejovidae). - J. Arachnol. 23: 60-64.

Received October 7, 2012; revised and accepted November 5, 2012 